УДК $634.8: 631.52: 663.2$

DOI 10.30679/2219-5335-2021-4-70-38-47

СОРТА ВИНОГРАДА

АЛЬКОР И ГРАНАТОВЫЙ
ДЛЯ ВЫСОКОКАЧЕСТВЕННОГО
ВИНОДЕЛИЯ

Ильницкая Елена Тарасовна канд. биол. наук зав. лабораторией сортоизучения и селекции винограда e-mail: ilnitskaya79@mail.ru

Агеева Наталья Михайловна д-р техн. наук, профессор главный научный сотрудник лаборатории виноделия e-mail: ageyeva@inbox.ru

Пята Елена Георгиевна младший научный сотрудник лаборатории сортоизучения и селекции винограда e-mail: pyata1983@mail.ru

Прах Антон Владимирович канд. с.-х. наук зав. лабораторией виноделия e-mail: aprakh@yandex.ru

Котляр Виктория Константиновна младший научный сотрудник лаборатории сортоизучения и селекции винограда e-mail: mayyyiva@gmail.com

Федеральное государственное бюджетное научное учреждение «Северо-Кавказский федеральный научный иентр садоводства, виноградарства, виноделия», Краснодар, Россия

Представлены основные биологические и хозяйственно ценные характеристики районированных сортов винограда селекции СКФНЦСВВ: Алькор и Гранатовый. Сорта винограда для высококачественного
UDC $634.8: 631.52: 663.2$

DOI 10.30679/2219-5335-2021-4-70-38-47

\section{ALCOR AND GRANATOVYI GRAPE VARIETIES FOR HIGH QUALITY WINE}

Ilnitskaya Elena Tarasovna Cand. Biol. Sci.

Head of Laboratory of Cultivar's study and Breeding of Grapes e-mail: ilnitskaya79@mail.ru

Ageyeva Natalia Mikhailovna Dr. Sci. Tech., Professor Chief Research Associate of Wine-making Laboratory e-mail: ageyeva@inbox.ru

Pyata Elena Georgievna Junior Research Associate of Laboratory of Cultivar's Study and Breeding of Grapes e-mail: pyata1983@mail.ru

Prakh Anton Vladimirovich Cand. Agr. Sci.

Head of Wine-making Laboratory e-mail: aprakh@yandex.ru

Kotlyar Victoria Konstantinovna Junior Research Associate of Laboratory of Cultivar's Study and Breeding of Grapes e-mail: mayyyiva@gmail.com

Federal State Scientific

Budget Institution «North-Caucasian Federal Scientific Center of Horticulture, Viticulture, Wine-making», Krasnodar, Russia

The main biological and economically valuable characteristics of the recognised grape varieties of the NCFSCHVW breeding are presented: Alcor and Granatovyi. Grapevine varieties 
красного виноделия были получены путём внутривидовых скрещиваний $V$. vinifera.

Генотипы адаптированы к местным условиям возделывания, сорта Алькор и Гранатовый превосходят Каберне-Совиньон по показателям устойчивости к патогенам в условиях юга России. Урожай винограда сортов Алькор и Гранатовый используется для получения высококачественных столовых и ликерных вин, а также виноградного сока.

Виноград сортов Алькор и Гранатовый характеризуется высоким технологическим запасом фенольных соединений, превышающим аналогичный показатель Каберне-Совиньон в среднем на $15 \%$. Вина были неоднократно отмечены высокими наградами на российских и международных конкурсах и выставках. Столовые красные вина из винограда сортов Алькор и Гранатовый характеризуются полным гармоничным вкусом и хорошо выраженным сортовым ароматом, высокой суммарной концентрацией фенольных соединений, в том числе антоцианов, обусловливающих интенсивную нарядную темно-рубиновую окраску. Ликерные вина также имеют очень интенсивную окраску, с выдержкой свойства ликерных вин улучшаются В столовых и ликерных винах из сортов Алькор и Гранатовый отмечается высокая концентрация антиоксидантов, в том числе ресвератрола и фенолкарбоновых кислот. Сорта Алькор и Гранатовый включены в Государственный реестр селекционных достижений РФ, допущенных к использованию Алькор в (2017 г.) и Гранатовый (1987 г.). Доказано, что сорта винограда отечественной селекции Алькор и Гранатовый достойные конкуренты европейских сортов для расширения линейки столовых и ликерных вин в условиях юга России.

Ключевые слова: ТЕХНИЧЕСКИЕ СОРТА ВИНОГРАДА, КРАСНЫЕ ВИНА, СЕЛЕКЦИЯ ВИНОГРАДА, РАЙОНИРОВАННЫЙ СОРТИМЕНТ for high-quality red wine production were obtained by intraspecific crosses of $V$. vinifera. The genotypes are adapted to the local conditions of cultivation, varieties Alcor and Granatovyi surpass Cabernet-Sauvignon in terms of resistance to pathogens in the conditions of the South of Russia. The Alcor and Granatovyi grape varieties are used to produce high-quality table and liqueur wines, as well as grape juice. The grapes of the Alcor and Granatovyi varieties are characterized by a high technological reserve of phenolic compounds, exceeding the similar indicator of Cabernet-Sauvignon by an average of $15 \%$. The wines have been repeatedly awarded high awards at Russian and international competitions and exhibitions. Table red wines from the Alcor and Granatovyi grape varieties are characterized by a full harmonious taste and a well-defined varietal aroma, a high total concentration of phenolic compounds, including anthocyanins, which cause an intense elegant dark ruby color. Liqueur wines also have a very intense color, with aging, the properties of liqueur wines are improved. Table and liqueur wines from the varieties Alcor and Granatovyi have a high concentration of antioxidants, including resveratrol and phenol-carboxylic acids. Alcor (2017) and Granatovyi (1987) varieties are included in the State Register of breeding achievements of the Russian Federation, approved for use. It is proved that the grapevine varieties of domestic breeding Alcor and Granatovyi are worthy competitors of European varieties for expanding the range of table and liqueur wines in the conditions of the south of Russia.

Key words: WINE GRAPVINE VARIETIES, RED WINES, GRAPE BREEDING, RECOGNISED VARIETIES 
Введение. Виноградная лоза (Vitis vinifera L.) - одна из старейших сельскохозяйственных культур в мире, которую выращивают для производства свежих ягод, сушёной продукции, сока и вина. Направление использования урожая зависит от сорта винограда. Каждый сорт винограда обладает индивидуальными биологическими свойствами, наиболее ценные из них адаптивный и продукционный потенциалы, устойчивость к биотическим и абиотическим стрессорам, качественные показатели винограда и винопродукции [1].

Экономическая эффективность производства определяется биологическими особенностями сорта, терруаром, используемыми агротехническими методами, а также погодными условиями конкретного года [2-9].

Согласно Федеральному закону № 468 «О виноградарстве и виноделии в Российской Федерации», вступившему в силу в июне 2020 года, продукция, обозначающаяся как «вино России», должна быть произведена исключительно из винограда, выращенного на территории страны. В настоящее время, вина могут быть произведены только из технических сортов винограда, которые введены в Государственный реестр Российской Федерации селекционных достижений, допущенных к использованию [10].

Вина, произведенные из красных сортов винограда, являются одной из наиболее востребованных позиций на рынке алкогольной продукции. Это обусловлено тем, что красные вина обладают насыщенным и терпким вкусом, в них повышенное содержание биологически активных веществ - антоцианов, катехинов, флавоноидов. Было подтверждено, что красные вина обладают многочисленными полезными свойствами и при употреблении в умеренных количествах могут способствовать укреплению здоровья человека [11-14].

Краснодарский край - основной регион виноградарства в Российской Федерации, значительные площади заняты классическими европейскими сортами для высококачественного виноделия (Каберне-Совиньон, Мерло, 
Шардоне, Совиньон) [15]. Однако отечественные сорта, созданные в агроклиматических условиях края, отобранные как наиболее адаптированные к местным экологическим факторам и проявляющие потенциал качества урожая в данной зоне виноградарства, могут составить достойную конкуренцию общеизвестным сортам и расширить линейку вин региона.

На базе ФГБНУ СКНФЦСВВ на протяжении более 70-ти лет ведется селекционная работа по созданию сортов винограда. К наиболее значимым результатам этой работы можно отнести технические сорта $V$. vinifera Гранатовый и Алькор, введённые в Государственный реестр селекционных достижений РФ, допущенных к использованию, их изучение и описание являлось целью нашей работы.

Объекты и методы исследований. Виноград сортов V. vinifera Гранатовый и Алькор были исследованы применительно к их использованию для получения высококачественных вин. Красные столовые виноматериалы готовили путем сбраживания мезги с применением активных сухих дрожжей расы Оеноферм руж (Германия). Для производства ликерных виноматериалов проводили термовинификацию мезги при температуре 55-60 ${ }^{\circ} \mathrm{C}$ с последующим отделением сусла, его подбраживанием и спиртованием с применением виноградного дистиллята. Массовую концентрацию суммы фенольных веществ определяли колориметрическим методом с применением реактива Фолина-Чокальтеу. Массовую концентрацию биологически активных веществ, в том числе витаминов, определяли методом капиллярного электрофореза (Капель 105Р).

Обсужжение результатов. Алькор - сорт винограда селекции СКФНЦСВВ, авторы Т.И. Гугучкина, Е.А. Даурова, Т.П. Зинченко, Л.Т. Коханова, Т.А. Нудьга, А.В. Передистый, Талаш А.И. Получен от скрещивания сортов Серексия х Каберне-Совиньон. Срок созревания - среднепоздний. 
Лист мелкий и средних размеров, округлый, среднерассеченный, с нижней стороны с опушением средней густоты. Верхняя сторона листа гладкая, блестящая. Боковые вырезки закрытые, щелевидные. Верхушки лопастей вытянуты в длинный зубчик. Черешковая выемка открытая, с широким дном. Черешок длиннее или равен средней жилке.

Гроздь среднего размера, средней плотности. Сахаристость сока ягод

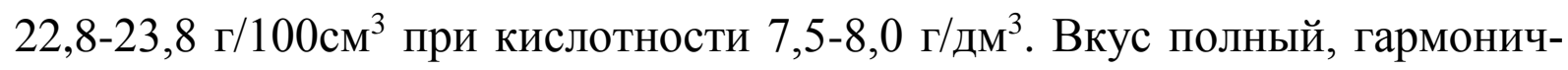
ный, с ярко выраженным пасленовым привкусом. Урожайность высокая, 8-10 кг с куста (рис. 1, рис. 2).

Кусты сильнорослые, вызревание побегов хорошее. Сорт отличается относительной толерантностью к филлоксере и может возделываться в корнесобственной культуре в зоне заражения филлоксерой. Морозостойкость сорта на уровне Каберне-Совиньон (минус $20-22^{\circ} \mathrm{C}$ ).

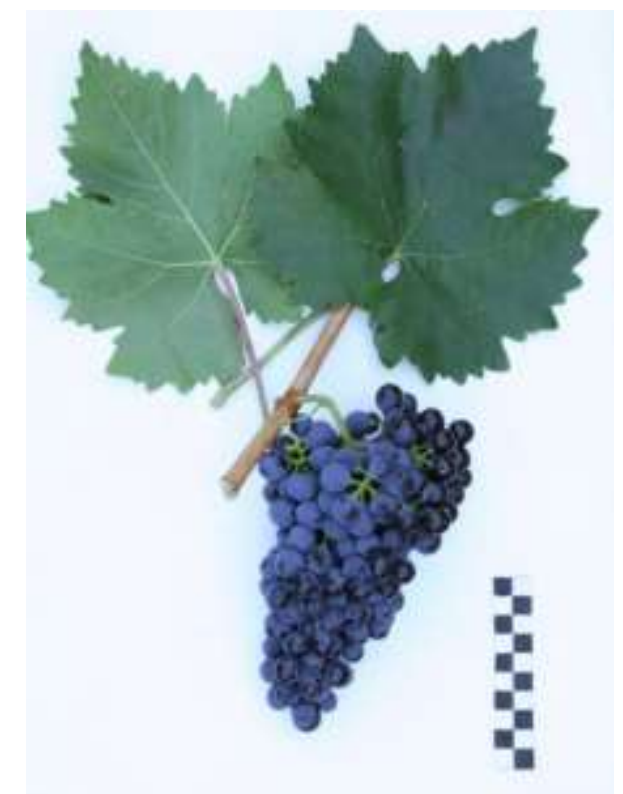

Рис. 1. Гроздь винограда сорта Алькор

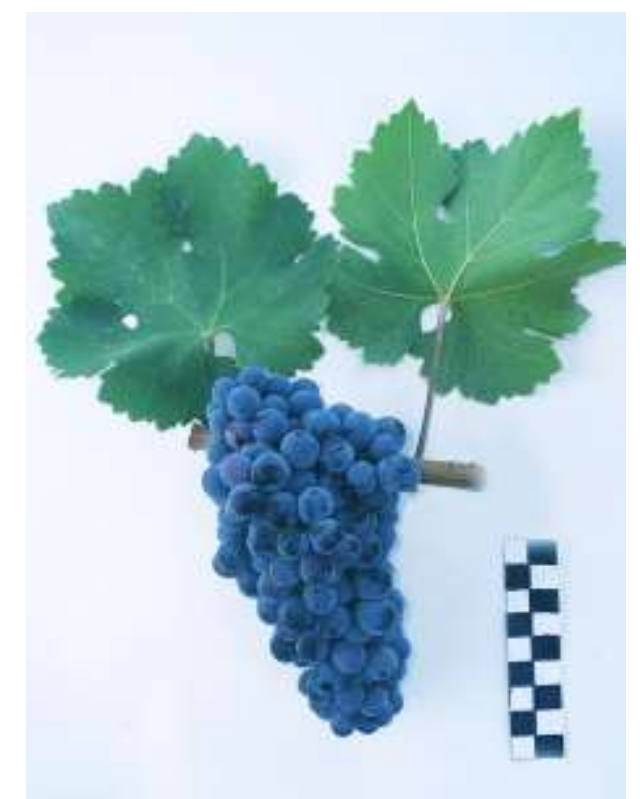

Рис. 2. Гроздь винограда сорта Гранатовый

Урожай сорта используется для приготовления красных высококачественных столовых и десертных вин типа Кагор. Столовые вина отличаются интенсивной окраской, тонким ароматом, полным гармоничным вкусом с пасленовым оттенком. Десертные вина имеют полный слаженный вкус, 
при выдержке развивается тонкий букет с медовыми и шоколадными тонами. Дегустационная оценка столовых вин 8,0-8,2 балла, десертных 8,5-8,9 баллов.

Гранатовый - сорт винограда селекции СКФНЦСВВ, авторы Коханова Л.Т., Зинченко Т.П. Получен от скрещивания сортов Саперави х Каберне-Совиньон. Срок созревания среднепоздний.

Лист средний, воронковидный, округлый, пятилопастный, средне или глубоко рассеченный с острыми зубчиками на концах лопастей и слабым щетинисто-паутинистым опушением. Черешок на освещенной солнцем стороне окрашен в винно-красный цвет. Ягода темно-синяя, средняя или мелкая, округлая, с сочной мякотью. Гроздь коническая, плотная и средней плотности. Средняя масса грозди 200 г. Урожайность высокая и стабильная, 9-11 кг с куста.

Куст среднерослый с тонкими побегами. Устойчивость к морозам - на уровне сорта Каберне-Совиньон (минус 20-22 ${ }^{\circ} \mathrm{C}$ ) (см. рис. 2).

У обоих сортов одной из родительских форм является Каберне-Совиньон как источник общепризнанного качества вина. Сорта Алькор и Гранатовый превосходят данный французский сорт по показателям устойчивости к патогенам в условиях юга России [16-18] (табл. 1).

Таблица 1 - Поражаемость основными болезнями и вредителями сортов Алькор и Гранатовый в сравнении с контролем (Каберне-Совиньон)

\begin{tabular}{|l|c|c|c|}
\hline \multicolumn{1}{|c|}{ Поражаемость } & Алькор & Гранатовый & $\begin{array}{c}\text { Каберне- } \\
\text { Совиньон }\end{array}$ \\
\hline \multicolumn{3}{|c|}{ Болезни, балл поражения } \\
\hline Милдью & 3,0 & 2,0 & $3,0-4,0$ \\
\hline Оидиум & 2,0 & 2,0 & 3,0 \\
\hline Серая гниль & 2,0 & 1,0 & 2,0 \\
\hline Белая гниль & 1,0 & 2,0 & 3,0 \\
\hline Черная пятнистость & 2,0 & 2,0 & 2,0 \\
\hline \multicolumn{4}{|c|}{ Вредители, балл } \\
\hline Корневая форма филлоксеры & $2-3$ & 3,5 & $4-4,5$ \\
\hline Листовая форма филлоксеры & 0 & $0-1$ & 0 \\
\hline
\end{tabular}


Плодоводство и виноградарство Юга России № 70(4), 2021 г.

Урожай винограда сортов Алькор и Гранатовый используется для получения высококачественных столовых и ликерных вин, а также виноградного сока. Виноград сортов Алькор и Гранатовый характеризуется высоким технологическим запасом фенольных соединений, превышающим аналогичный показатель Каберне-Совиньон в среднем на 15 \%.

Столовые красные вина характеризуются полным гармоничным вкусом и хорошо выраженным сортовым ароматом, высокой суммарной концентрацией фенольных соединений, в том числе антоцианов, обусловливающих интенсивную нарядную темно-рубиновую окраску (табл. 2).

Таблица 2 - Фенольные соединения исследуемых сортов винограда

\begin{tabular}{|l|c|c|c|c|c|c|}
\hline \multirow{2}{*}{$\begin{array}{c}\text { Фенольные } \\
\text { соединения }\end{array}$} & \multicolumn{6}{|c|}{ Массовая концентрация фенольных соединений, мг/дм ${ }^{3}$} \\
\cline { 2 - 7 } & \multicolumn{7}{|c|}{ Столовое вино } & \multicolumn{3}{c|}{ Ликерное вино } \\
\cline { 2 - 7 } & Гранатовый & Алькор & $\begin{array}{c}\text { Каберне- } \\
\text { Совиньон }\end{array}$ & Гранатовый & Алькор & $\begin{array}{c}\text { Каберне- } \\
\text { Совиньон }\end{array}$ \\
\hline Сумма & 4210 & 4860 & 3760 & 4680 & 5130 & 4110 \\
\hline Антоцианы & 480 & 540 & 420 & 530 & 580 & 450 \\
\hline Ресвератрол & 5,16 & 5,56 & 3,52 & 6,12 & 7,84 & 5,52 \\
\hline \multicolumn{7}{|c|}{ Фенолкарбоновые кислоты } \\
\hline Хлорогеновая & 7,56 & 6,25 & 5,72 & 7,03 & 7,56 & 8,23 \\
\hline Никотиновая & 8,56 & 8,22 & 7,64 & 8,78 & 9,12 & 8,23 \\
\hline Оротовая & 38,0 & 39,5 & 37,3 & 46,7 & 46,1 & 43,2 \\
\hline Кофейная & 9,06 & 7,45 & 8,23 & 8,67 & 9,02 & 7,92 \\
\hline Галловая & 92,6 & 94,8 & 74,2 & 121,6 & 118,3 & 92,8 \\
\hline Протокатеховая & 3,90 & 3,03 & 4,16 & 5,06 & 5,34 & 6,71 \\
\hline
\end{tabular}

Ликерные вина - кагоры, портвейны - также имеют очень интенсивную окраску, обусловленную высокой концентрацией антоцианов (см. табл. 2), полный, слаженный и мягкий вкус с яркими тонами красных ягод и фруктов, в том числе чернослива, терна. С выдержкой свойства ликерных вин улучшаются.

В столовых и ликерных винах из сортов Алькор и Гранатовый отмечается высокая концентрация антиоксидантов, в том числе ресвератрола, 
фенолкарбоновых кислот, обладающих антиканцерогенными, антиаллергенными, антисклеротическими и противовоспалительными свойствами, обеспечивающих профилактику многих заболеваний и корректирующих антиоксидантный статус человека $[19,20,21]$.

Вина из урожая исследуемых сортов винограда неоднократно были отмечены высокими наградами на российских и международных конкурсах и выставках. Так, на международном конкурсе «Ялта. Золотой грифон-2009» десертное красное вино «Алькор» удостоено золотой медали. На 12-й международной выставке «Вина и напитки. Интервитис Интерфрукта России 2009» вино специальное красное «Алькор» отмечено бронзовой медалью.

Вино ликёрное из винограда сорта Гранатовый урожая 2014 г. удостоено золотой медали «Золотая осень». Вино столовое сухое красное «Гранатовый» удостоено золотых медалей на конкурсах «Ялта. Золотой грифон-2017» и «Ялта. Золотой грифон-2018».

Bblвodb. Таким образом результаты исследований показывают, что сорта винограда отечественной селекции Алькор и Гранатовый достойные конкуренты европейским сортам, расширяющие линейки столовых и ликерных вин.

\section{Литература}

1. Егоров Е.А., Петров В.С. Создание устойчивых саморегулирующихся агроценозов винограда в условиях умеренно-континентального климата юга России // Вестник российской сельскохозяйственной науки. 2017. Т. 5. С. 51-54.

2. Jones, G.V.; White, M.A.; Cooper, O.R.; Storchmann, K. Climate change and global wine quality // Clim. Chang. 2005. №7. C. 319-343.

3. Macqueen, R.W.; Meinert, L.D. (Eds.) Fine Wine and Terroir - The Geoscience Perspective; Geological Association of Canada Geoscience, Canada Reprint Series: St. John's, NL, Canada, 2006; ISBN 978-1-897095-21-8.

4. Gladstones, J. Wine, Terroir and Climate Change; Wakefield Press: Kent Town, South Australia. 2011. C. 280.

5. Novikova L.Y., Naumova L.G. Dependence of Fresh Grapes and Wine Taste Scores on the Origin of Varieties and Weather Conditions of the Harvest Year in the Northern Zone of Industrial Viticulture in Russia //Agronomy. 2020. T.10. № 10. C. 1613.

6. Петров В.С., Павлюкова Т.П., Талаш А.И. Научные основы устойчивого выращивания винограда в аномальных погодных условиях. Краснодар: ООО «ПросвещениеЮг», 2014. $157 \mathrm{c}$. 
7. Петров В.С. Формирование адаптивного сортимента винограда в нестабильных условиях среды [Электронный ресурс] // Плодоводство и виноградарство Юга России. 2013. № 20(2). C. 15-30. URL: http://journalkubansad.ru/pdf/13/02/03.pdf. (дата обращения: 09.06.2021).

8. Егоров Е.А., Петров В.С., Панкин М.И. Потенциал продуктивности винограда: проблемы его реализации на промышленных насаждениях юга России // Виноделие и виноградарство. 2007. № 3. С. 7.

9. Егоров Е.А., Шадрина Ж.А., Кочьян Г.А. Функциональные взаимосвязи и взаимовлияния, определяющие устойчивость и эффективность воспроизводственных процессов в промышленном виноградарстве // Научный журнал КубГАУ. 2016. № 122(08), C. 669-680.

10. О виноградарстве и виноделии в Российской Федерации: Федер. Закон [Принят Гос. Думой 27.12.2019] // Собрание законодательств РФ. 2021. Доступ из справ.-правовой системы «КонсультантПлюс».

11. Gonzalo-Diago A., Dizy M., Fernández-Zurbano P. Contribution of low molecular weight phenols to bitter taste and mouthfeel properties in red wines // Food Chemistry. 2014. №154. pp. 187-198.

12. Kirakosyan E.M., Seymour N., Kondoleon E., Gutierrez J., Wolforth S. Bolling. The intake of red raspberry fruit is inversely related to cardiac risk factors associated with metabolic syndrome // Journal of Functional Foods. 2018. №41. pp. 83-89.

13. Николаева М.А., Рязанова О. А. Польза и вред алкогольных напитков // Товаровед продовольственных товаров. 2020. №. 1. С. 29-35.

14. Castaldo L., Narváez A., Izzo L., Graziani G., Gaspari A., Di Minno G., Ritieni A. Red wine consumption and cardiovascular health //Molecules. 2019. T. 24. №.19. C. 3626.

15. Современные методологические аспекты организации селекционного процесса в садоводстве и виноградарстве / под ред. Г.В. Еремина. Краснодар: СКЗНИИСиВ, 2012. 569 с.

16. Нудьга Т.А., Ильницкая Е.Т., Даурова Е.А. Агробиологическая оценка технических сортов винограда Алькор и Антарис в условиях Тамани [Электронный ресурс] // Плодоводство и виноградарство Юга России. 2017. № 43(1). C. 22-29. URL: http://journalkubansad.ru/pdf/17/01/03.pdf. (дата обращения: 09.06.2021).

17. Сорта селекции СКЗНИИСИВ для импортозамещения и совершенствование отечественного сортимента технического винограда / Е.Т. Ильницкая [и др.] // Садоводство и виноградарство. 2016. № 5. С. 31-36.

18. Перспективные сорта селекции СКЗНИИСИВ для качественного виноделия / Т.А. Нудьга [и др.] // Виноделие и виноградарство. 2010. № 4. С. 28-30.

19. Авидзба А.М., Агеева Н.М, Гугучкина Т.И., Маркосов В.А. Красные столовые вина: биохимия, технология, энотерапия. Краснодар, 2016. 192 с.

20. Ellen Silva Lago-Vanzela / Aging of red wines made from hybrid grape cv. BRS Violeta: Effects of accelerated aging conditions on phenolic composition, color and antioxidant activity / Food Research International, 2014. 23 p.

21. Биологически активные вещества винограда и здоровье: монография / под общ. ред. А.Л. Загайко. Харьков: Форт, 2012. 404 с.

\section{References}

1. Egorov E.A., Petrov V.S. Sozdanie ustojchivyh samoreguliruyushchihsya agrocenozov vinograda v usloviyah umerenno-kontinental'nogo klimata yuga Rossii // Vestnik rossijskoj sel'skohozyajstvennoj nauki. 2017. T. 5. S. 51-54.

2. Jones, G.V.; White, M.A.; Cooper, O.R.; Storchmann, K. Climate change and global wine quality // Clim. Chang. 2005. №7. S. 319-343. 
3. Macqueen, R.W.; Meinert, L.D. (Eds.) Fine Wine and Terroir - The Geoscience Perspective; Geological Association of Canada Geoscience, Canada Reprint Series: St. John's, NL, Canada, 2006; ISBN 978-1-897095-21-8.

4. Gladstones, J. Wine, Terroir and Climate Change; Wakefield Press: Kent Town, South Australia. 2011. S. 280.

5. Novikova L.Y., Naumova L.G. Dependence of Fresh Grapes and Wine Taste Scores on the Origin of Varieties and Weather Conditions of the Harvest Year in the Northern Zone of Industrial Viticulture in Russia //Agronomy. 2020. T.10. № 10. S. 1613.

6. Petrov V.S., Pavlyukova T.P., Talash A.I. Nauchnye osnovy ustojchivogo vyrashchivaniya vinograda $\mathrm{v}$ anomal'nyh pogodnyh usloviyah. Krasnodar: OOO «ProsveshchenieYug», 2014. $157 \mathrm{~s}$.

7. Petrov V.S. Formirovanie adaptivnogo sortimenta vinograda v nestabil'nyh usloviyah sredy [Elektronnyj resurs] // Plodovodstvo i vinogradarstvo Yuga Rossii. 2013. № 20(2). S. 15-30. URL: http://journalkubansad.ru/pdf/13/02/03.pdf. (data obrashcheniya: 09.06.2021).

8. Egorov E.A., Petrov V.S., Pankin M.I. Potencial produktivnosti vinograda: problemy ego realizacii na promyshlennyh nasazhdeniyah yuga Rossii // Vinodelie i vinogradarstvo. 2007. № 3. S. 7.

9. Egorov E.A., Shadrina Zh.A., Koch'yan G.A. Funkcional'nye vzaimosvyazi i vzaimovliyaniya, opredelyayushchie ustojchivost' i effektivnost' vosproizvodstvennyh processov v promyshlennom vinogradarstve // Nauchnyj zhurnal KubGAU. 2016. № 122(08). S. 669-680.

10. O vinogradarstve i vinodelii v Rossijskoj Federacii: Feder. Zakon [Prinyat Gos. Dumoj 27.12.2019] // Sobranie zakonodatel'stv RF. 2021. Dostup iz sprav. pravovoj sistemy «Konsul'tantPlyus».

11. Gonzalo-Diago A., Dizy M., Fernández-Zurbano P. Contribution of low molecular weight phenols to bitter taste and mouthfeel properties in red wines // Food Chemistry. 2014. №154. pp. 187-198.

12. Kirakosyan E.M., Seymour N., Kondoleon E., Gutierrez J., Wolforth S. Bolling. The intake of red raspberry fruit is inversely related to cardiac risk factors associated with metabolic syndrome // Journal of Functional Foods. 2018. №41. pp. 83-89.

13. Nikolaeva M.A., Ryazanova O. A. Pol'za i vred alkogol'nyh napitkov // Tovaroved prodovol'stvennyh tovarov. 2020. №. 1. S. 29-35.

14. Castaldo L., Narváez A., Izzo L., Graziani G., Gaspari A., Di Minno G., Ritieni A. Red wine consumption and cardiovascular health // Molecules. 2019. T. 24. №.19. S. 3626.

15. Sovremennye metodologicheskie aspekty organizacii selekcionnogo processa v sadovodstve i vinogradarstve / pod red. G.V. Eremina. Krasnodar: SKZNIISiV, 2012. $569 \mathrm{~s}$.

16. Nud'ga T.A., Il'nickaya E.T., Daurova E.A. Agrobiologicheskaya ocenka tekhnicheskih sortov vinograda Al'kor i Antaris v usloviyah Tamani [Elektronnyj resurs] // Plodovodstvo i vinogradarstvo Yuga Rossii. 2017. № 43(1). S. 22-29. URL: http://journalkubansad.ru/pdf/17/01/03.pdf. (data obrashcheniya: 09.06.2021).

17. Sorta selekcii SKZNIISIV dlya importozameshcheniya i sovershenstvovanie otechestvennogo sortimenta tekhnicheskogo vinograda / E.T. Il'nickaya [i dr.] // Sadovodstvo i vinogradarstvo. 2016. № 5. S. 31-36.

18. Perspektivnye sorta selekcii SKZNIISIV dlya kachestvennogo vinodeliya / T.A. Nud'ga [i dr.] // Vinodelie i vinogradarstvo. 2010. № 4. S. 28-30.

19. Avidzba A.M., Ageeva N.M, Guguchkina T.I., Markosov V.A. Krasnye stolovye vina: biohimiya, tekhnologiya, enoterapiya. Krasnodar, 2016. $192 \mathrm{s.}$

20. Ellen Silva Lago-Vanzela / Aging of red wines made from hybrid grape cv. BRS Violeta: Effects of accelerated aging conditions on phenolic composition, color and antioxidant activity / Food Research International, 2014. 23 r.

21. Biologicheski aktivnye veshchestva vinograda i zdorov'e: monografiya / Pod obshch. red. A.L. Zagajko. Har'kov: Fort, 2012. 404 s. 